\title{
Roasting Coffee Sales Prediction for Demand Satisfaction
}

\author{
Aldo Wicaksono Wibowo* \\ Accounting Department \\ State Polytechnic of Malang \\ Malang, Indonesia \\ *wicaksonoaldo95@gmail.com
}

\begin{abstract}
The purpose of this study is to predict sales of coffee roasting at the Café (Coffee and Roastery) Philosophy in 2021. This research was conducted using sales data from 2018 2020. The primary data for roasted coffee is sales data. This type of research is quantitative, using excel software tools. This study indicates that the forecasting of coffee roasting sales in the Café philosophy (Coffee and Roastery) suggests an increase in sales, although not too much because of limited production capacity.
\end{abstract}

Keywords—forecasting, moving average, single moving average

\section{INTRODUCTION}

The thing that needs to be considered before making forecast is to know in advance what the real problem or issue is in a decision to be taken [1], Philosophy (Coffee and Roastery) facing the problem that occur in imbalance between the demand or sales of coffee roasting with the current production capacity. It is hoped that with the projected demand or sales forecasting, the owner and management of Philosophy (Coffee and Roastery) can predict the sales to meet customer satisfaction.

Accounting information system will make it easier for companies to carry out most of the company activities. By providing precise and accurate information, production cost can be more effective and efficient. Record and report is and organizations form to provide financial systems also allows business owners to forecast the products they sell so that with forecasting owners can maximize the result of sales [2]. Forecasting is the prediction of what will happen in the future, while planning is the determination of what will be done in the future. By itself there is a difference between forecast and plan [3]. Forecasting is a prediction, projection, or estimation or the level of events where it is uncertain in the future [4], moving average is a method of forecasting that is done by taking a group of observed values, looking for the average value as a prediction for the coming period [5]. Forecasting is a method for estimating a value in the future using past data, forecasting can also be interpreted as the art and science to predict future events, whereas forecasting activity is a business function that seeks to estimate the sales or use of a product so that products can be made in the right quantity [6].
The coffee plantation area in Indonesia area in Indonesia reached more than 1.24 million hectares, whereas 933 hectares in Robusta plantation and 307 hectares is Arabica plantation. The total of commodities production reached 685tons, which $90 \%$ of it was coffee. The average of coffee areas development in Indonesia reached $2.11 \%$ per year. According to the data from the Indonesia Coffee Exporters Association (AEKI), Indonesia's abbreviation, red. Indonesian farmers along with relevant ministries plan to expand Indonesia's coffee plantation, while rejuvenating old plantations through intensification programs. By increasing the area of plantations Indonesia, coffee production in the next 10 years is targeted to reach between 900 thousand tons to 1.2 million tons per year [7]. Forecasting according to is a prediction, projection or estimate of the level of events where it is uncertain in the future. Accurately predicting events and the level of future events cannot always be achieved, therefore when companies are unable to see future events with certainty, this is where companies need a lot of time and energy so they can have the power to draw conclusions. to the events to come. Therefore, forecasting is needed by a company or government agency to develop strategies that are preventive in nature to minimize risks that may occur in the future [8].

Business has the main purpose and objective of seeking profit. The development of the coffee industry in the Malang region of East Java, accompanied by the development of technology and various facilities for starting a business, has impacted the progress and development of various businesses around us. One of the business fields that are currently popular with young people, especially in Malang, is culinary business of coffee or cafes. With the progress and development of the café business in Malang, there are great opportunities in the coffee roasting sales segment. This opportunity is put to good use by Philosophy Café (Coffee and Roastery), one of the cafes in Malang, precisely in Turen, Malang Regency.

This study has new novelty that forecasting carried out at Philosophy of café (Coffee and Roastery) can be used as an estimation tool to maximize sales to meet customer satisfaction which was not discussed in previous studies. It is important to help owner and management to improve their business. 
With the increase of the Indonesian coffee industry, now coffee has become part of most Indonesians' lifestyle. Along with the development of the coffee drinking culture and the development of the coffee roasting industry in Malang, the philosophy of the Café (coffee and roastery) experiences limitations in meeting the capacity for coffee roasting demand due to the absence of sales projections in the current business process. The purpose of this study was to determine the result of forecasting and to analyze the project coffee roasting sales at Philosophy Café (Coffee and Roastery) to meet the sales quota and customer satisfaction in 2021.

\section{METHODS}

The method used to calculate forecasting for coffee roasting sales uses quantitative forecasting, namely the moving average method. This study's data uses demand or sales data starting from 2018 to 2020 and the data obtained is primary data. The data obtained is historical sales data that is then processed using forecasting methods to predict the number of levels of demand or sales of coffee roasting that occur at the Café (Coffee and Roastery) Philosophy. To obtain forecast results, use excel and formulas. Forecasting the number of requests or sales of coffee roasting is calculated using Excel software; using this software can make it easier to research predicting the level of coffee roasting sales in 2021 based on historical data.

\section{RESULTS AND DISCUSSION}

Data collection on actual market demand or sales is obtained from the company with reference to the amount of income received from consumers, starting from January 2018 to December 2020. The following data on coffee roasting sales can be seen in table 1 :

TABLE I. SALES DATA 2018-2020

\begin{tabular}{|c|c|c|c|c|}
\hline No & Months & 2018 & 2019 & 2020 \\
\hline 1 & January & Rp9,535,000 & Rp15,080,000 & Rp15,820,000 \\
\hline 2 & February & Rp8,099,000 & Rp15,867,000 & Rp18,653,000 \\
\hline 3 & March & Rp11,044,000 & Rp11,875,000 & Rp18,908,000 \\
\hline 4 & April & Rp11,363,000 & Rp14,464,000 & Rp14,643,000 \\
\hline 5 & Mei & Rp11,796,000 & Rp12,021,000 & Rp19,085,000 \\
\hline 6 & June & Rp24,854,000 & Rp20,998,000 & Rp20,998,000 \\
\hline 7 & July & Rp11,824,000 & Rp9,995,000 & Rp9,995,000 \\
\hline 8 & August & Rp10,754,000 & Rp11,814,500 & Rp11,814,500 \\
\hline 9 & September & Rp11,793,000 & Rp9,853,000 & Rp9,853,000 \\
\hline 10 & October & Rp12,675,000 & Rp9,231,000 & Rp29,536,000 \\
\hline 11 & November & Rp14,312,000 & Rp9,255,000 & Rp31,788,000 \\
\hline 12 & December & Rp17,511,000 & $\mathrm{Rp} 18,250,000$ & $\operatorname{Rp} 37,237,000$ \\
\hline & Total & Rp155,560,000 & Rp158,703,500 & Rp238,330,500 \\
\hline
\end{tabular}

Source: Coffee and Roastery 2020

Based on the actual sales data from 2018 to 2020, the following graphs can be made from this data:

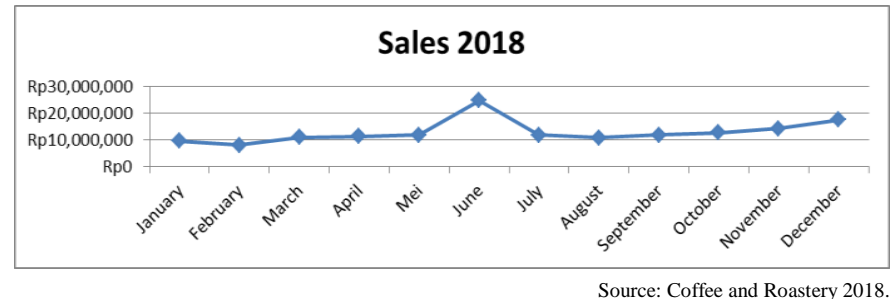

Fig. 1. Sales 2018

Based on figure 1, the actual sales data from 2018 to 2020 can be made from the following graph, it can be seen in the sales chart that sales achievement in 2018 tends to be stable and the peak sales were recorded in June, which is Rp. $24,854,000$. Then for sales in the following months throughout 2018, the level of sales achievement has a steady increase and is closed with a total sales turnover of Rp 155,560,000.

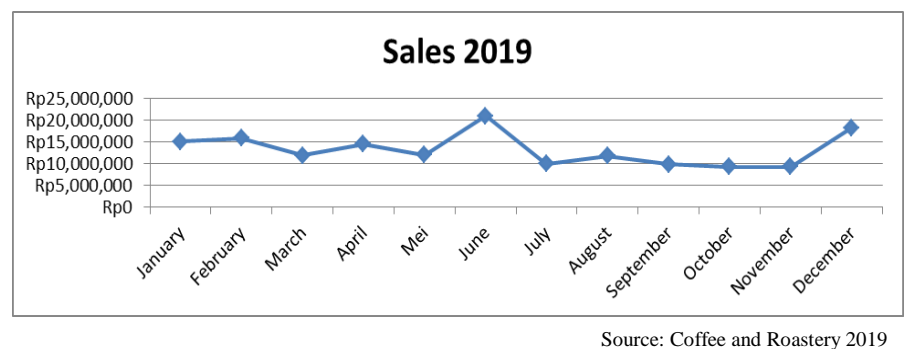

Fig. 2. Sales 2019

In figure 2, the sales data recorded in 2019, the sales level in the first semester, there was a significant increase compared to 2018 , but entering the month of July there was a decrease in sales turnover because according to the informant's statement that in July 2019 the Café (Coffee and Roastery) Philosophy carried out renovations and operating hours are shorter than before. Although there had been a decrease in sales turnover, there was a growth in the achievement of sales turnover in 2019, amounting to Rp. 3,143,000 compared to 2018 and with a total sales turnover in 2019 of Rp. 158,703,500.

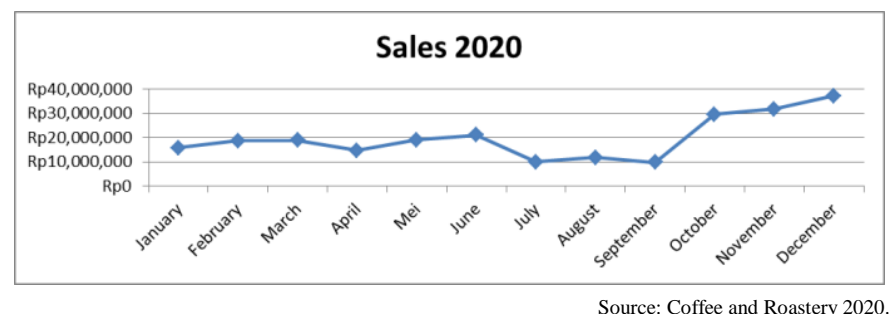

Fig. 3. Sales 2020.

In figure 3 sales data for 2020, this year's sales achievement looks quite fluctuating and data shows that the lowest sales achievement occurred in September because Philosophy Café (Coffee and Roastery) cannot fulfill the demand, namely Rp. $9,853,000$. To meet the increasing sales in future, it is hoped that the forecasting that has been done can be good guide in order to maximize sales and achieve customer satisfaction. Even though the achievement had decreased, in 2020 the sales 
level of the Philosophy Café (Coffee and Roastery) was the best achievement compared to previous years with recorded sales achievements in 2020 increasing by Rp. 79,627,000 compared to 2019 and closing sales in 2020 was recorded at Rp. 238,330,500

Sales data for the period 2018 to 2020 looks fluctuating. The data will then be predicted using the moving average forecasting method, where the calculations are carried out using a 6-month period. This method is calculated in a way, each new actual data can be calculated by removing the old data for the old period and entering the latest data for the period. In the calculation, the forecasting projection in this calculation uses a formula

$$
\begin{aligned}
& \boldsymbol{M}_{\boldsymbol{t}}=\boldsymbol{F}_{\boldsymbol{t}}+\mathbf{1} \\
& =\frac{Y t+Y t-1+Y t-2+\cdots+Y t-n+1}{n} \\
& F_{t+1}=\frac{\sum_{i=t}^{t-N+1} X i}{N}
\end{aligned}
$$

Following are the results of forecasting a 6-month single

\begin{tabular}{|c|c|c|c|}
\hline Year & Months & Sales & Forecasting \\
\hline \multirow[t]{12}{*}{2018} & January & Rp9,535,000 & \\
\hline & February & Rp8,099,000 & \\
\hline & March & Rp11,044,000 & \\
\hline & April & Rp11,363,000 & \\
\hline & Mei & Rp11,796,000 & \\
\hline & June & Rp24,854,000 & \\
\hline & July & Rp11,824,000 & Rp12,781,833 \\
\hline & August & Rp10,754,000 & Rp13,163,333 \\
\hline & September & Rp11,793,000 & Rp13,605,833 \\
\hline & October & Rp12,675,000 & $\begin{array}{l}\text { Rp13,730,667 } \\
\end{array}$ \\
\hline & November & Rp14,312,000 & Rp13,949,333 \\
\hline & December & Rp17,511,000 & Rp14,368,667 \\
\hline \multirow[t]{12}{*}{2019} & January & Rp15,080,000 & Rp13,144,833 \\
\hline & February & Rp15,867,000 & Rp13,687,500 \\
\hline & March & $\operatorname{Rp} 11,875,000$ & Rp14,539,667 \\
\hline & April & Rp14,464,000 & Rp14,553,333 \\
\hline & Mei & Rp12,021,000 & Rp14,851,500 \\
\hline & June & Rp20,998,000 & Rp14,469,667 \\
\hline & July & Rp9,995,000 & Rp15,050,833 \\
\hline & August & Rp11,814,500 & Rp14,203,333 \\
\hline & September & Rp9,853,000 & Rp13,527,917 \\
\hline & October & Rp9,231,000 & Rp13,190,917 \\
\hline & November & Rp9,255,000 & Rp12,318,750 \\
\hline & December & Rp18,250,000 & Rp11,857,750 \\
\hline \multirow[t]{12}{*}{2020} & January & Rp15,820,000 & Rp11,399,750 \\
\hline & February & Rp18,653,000 & Rp12,370,583 \\
\hline & March & Rp18,908,000 & Rp13,510,333 \\
\hline & April & Rp14,643,000 & Rp15,019,500 \\
\hline & Mei & Rp19,085,000 & Rp15,921,500 \\
\hline & June & Rp20,998,000 & Rp17,559,833 \\
\hline & July & Rp9,995,000 & Rp18,017,833 \\
\hline & August & $\operatorname{Rp} 11,814,500$ & Rp17,047,000 \\
\hline & September & Rp9,853,000 & Rp15,907,250 \\
\hline & October & Rp29,536,000 & Rp14,398,083 \\
\hline & November & $\operatorname{Rp} 31,788,000$ & Rp16,880,250 \\
\hline & December & $\operatorname{Rp} 37,237,000$ & Rp18,997,417 \\
\hline \multirow[t]{6}{*}{2021} & January & & Rp21,703,917 \\
\hline & February & & Rp24,045,700 \\
\hline & March & & $\operatorname{Rp} 27,103,500$ \\
\hline & April & & Rp32,853,667 \\
\hline & Mei & & $\operatorname{Rp} 34,512,500$ \\
\hline & June & & $\operatorname{Rp} 37,237,000$ \\
\hline
\end{tabular}
Moving Average:

TABLE II. Result of Forecasting SAles 6 months Single Moving Average 
Based on forecasting data conducted 6 months on table 3, sales for January 2021 is predicted to be at Rp. 21,703,917, February Rp. 24,045,700, March Rp. 27,103,500, April Rp. 32,853,667, Mei Rp. 34,512,500 and for June Rp. 37,237,000. With the data above, we can see the sales trend with a graph which is illustrated as follows:

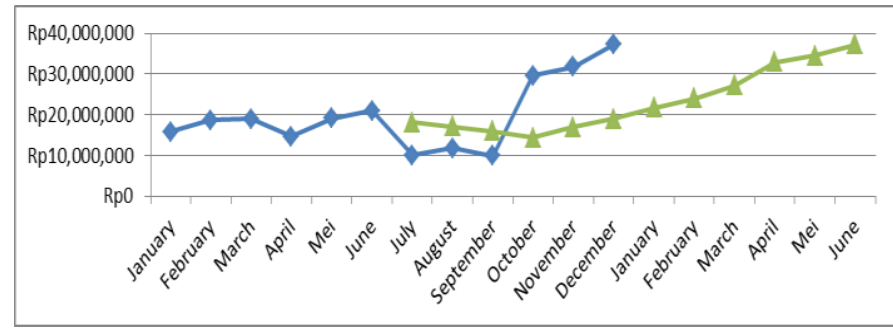

Source: Forecasting predicted 6 month sales 2021

Fig. 4. Sales trend.

Figure 4 shows in 2021, the first semester sales are predicted to be stable with an average sales achievement of Rp. 29,576,047. Based on forecasting data conducted 6 months, it is expected that in 2021 the first semester will generate sales growth of Rp. 11,558,214 compared to the first half of 2019.

\section{CONCLUSION}

This study uses a single moving average forecasting method to predict the number of requests or sales of coffee roasts at the Philosophy Café (Coffee and Roastery). The forecasting demand or sales of coffee roasts at the Philosophy Café (Coffee and Roastery) shows an increase in sales, although not too much because of limited production capacity. Based on the findings, it is hoped that it will support the owner and the management of philosophy Café (Coffee and Roastery) regarding planning and making decisions about demand or sales. Particularly for fulfilling orders in large quantities so that all incoming orders can be served and appropriately fulfilled, roasting customers' coffee is increasingly satisfactory in terms of products and services provided by Philosophy Café (Coffee and Roastery).

It is recommended more analysis be conducted prior to forecasting in order to ensure an understanding of the essence of the true problem to be dealt with and considerations of a given time period be understood prior to making a decision (Long Term).

\section{REFERENCES}

[1] M. Qamal, "Ringan Dengan Metode Single," 2019.

[2] Mulyadi, Sistem Informasi Akuntansi. Edisi ke-empat. 2016

[3] A. Mustofa, N. Eltivia, and Z.A. Haris, "Kontribusi Peramalan Penerimaan Mahasiswa Baru Politeknik: Sebagai Alat Estimasi Pendapatan," Media Mahard., vol. 18, no. 2, p. 266, 2020.

[4] Kurniagara, "Penerapan Metode Exponential Smoothing Dalam Memprediksi Jumlah Siswa Baru,” J. Pelita Inform., vol. 16, no. 3, pp. 214-220, 2017.

[5] R. Rachman, "Penerapan Metode Moving Average Dan Exponential Smoothing Pada Peramalan Produksi Industri Garment,” J. Inform., vol 5, no. 2, pp. 211-220, 2018.

[6] S. Wardah and I. Iskandar, "Analisis Peramalan Penjualan Produk Keripik Pisang Kemasan Bungkus (Studi Kasus: Home Industry Arwana Food Tembilahan)," J@ti Undip J. Tek. Ind., vol. 11, no. 3, p. 135, 2017.

[7] I. Mawardi, N. Nurdin, and Z. Zulkarnaini, "Appropriate Technology Program of Postharvested Coffee: Production, Marketing, and Coffee Processing Machine Business Unit," J. Pengabdi. Kpd. Masy. (Indonesian J. Community Engag., vol. 5, no. 2, p. 267, 2019.

[8] I.L.P. Navalina, N.I. Riwajanti, S. Sulistyono, and L. Djajanto, "Forecasting Produksi Perikanan Laut Yang Dijual Di Tpi (Ton) Dengan Metode Single Exponential Smoothing," Media Mahard., vol. 18, no. 2, p. $206,2020$. 